\title{
Treatment Adherence to Nucleos(t)ide Analogs in Chinese Patients with Hepatitis B Virus-Related Hepatocellular Carcinoma: A Single-Center Cross-Sectional Study
}

\author{
Yueyue $\mathrm{Li}^{1, *}$ \\ Anni Chen ${ }^{2, *}$ \\ Hui Wang ${ }^{2}$ \\ Lu Han' \\ Rong Wang' \\ Guoqing Zhang ${ }^{2}$ \\ Yongfang Yuan ${ }^{\text {I }}$ \\ 'Department of Pharmacy, Shanghai \\ Ninth People's Hospital, Shanghai \\ jiaoTong University School of Medicine, \\ Shanghai, 2000II, People's Republic of \\ China; ${ }^{2}$ Department of Pharmacy, Eastern \\ Hepatobiliary Surgery Hospital Affiliated \\ to Second Military Medical University, \\ Shanghai, 200438, People's Republic of \\ China
}

*These authors contributed equally to this work
Correspondence: Yongfang Yuan Department of Pharmacy, Shanghai Ninth People's Hospital, Shanghai JiaoTong University School of Medicine, Shanghai, 2000 II, People's Republic of China

Fax +862156786907

Email nmxyyf@126.com
Purpose: Chronic hepatitis B virus (HBV) infection is a crucial risk factor in the occurrence and development of hepatocellular carcinoma (HCC). Antiviral therapy is very important for patients with HBV-related HCC. To maintain undetectable level of HBV DNA, patients must take nucleos(t)ide analogues (NUCs) appropriately and regularly. We explored the adherence of Chinese patients with HBV-related HCC to antiviral treatment.

Patients and Methods: One-hundred and eighty-one patients were included in a crosssectional study between August 2020 and February 2021. A structured questionnaire was used to interview patients, and a form was applied to collect data from electronic medical records. Medication adherence was measured using a visual analog scale. Data of the adherent group and non-adherent group were compared using Student's $t$-test and the chisquare test. Multivariate logistic regression analysis was employed to explore independent risk factors that affected adherence behavior.

Results: High adherence was reported in $46.4 \%$ of patients with HBV-related HCC. Patients with high adherence were more likely to be women $(\mathrm{P}=0.02)$, shun alcohol $(\mathrm{P}=0.01)$, take NUCs other than entecavir $(\mathrm{P}=0.04)$, and pay attention to their titer of HBV DNA $(\mathrm{P}=0.05)$. Sex, alcohol consumption, and taking entecavir were independent risk factors for low adherence $(\mathrm{P}<0.05)$. The prevalence of virological breakthrough was lower in patients who adhered to NUC therapy than in those who did not, but the difference was not significant $(\mathrm{P}=0.31)$.

Conclusion: The adherence of patients with HBV-related HCC to NUC therapy was low. More attention should be paid to adherence of antiviral therapy in patients with HBV-related HCC.

Keywords: hepatocellular carcinoma, chronic hepatitis B, adherence, nucleos(t)ide analogs, virological breakthrough

\section{Introduction}

According to the National Central Cancer Registry of China, hepatocellular carcinoma (HCC) is the second leading cause of cancer-related death in China; 15.29 per 100,000 persons with $\mathrm{HCC}$ died in $2014 .{ }^{1}$ Chronic infection with the hepatitis $\mathrm{B}$ virus (HBV), which leads to $\sim 80 \%$ of HCC cases in China, is a crucial risk factor in the occurrence and development of $\mathrm{HCC}^{2}$ The manner by which chronic HBV infection causes HCC includes induction of liver fibrogenesis, genetic and epigenetic alterations, and expression of active viral-coded proteins. Efficacious antiHBV treatment to prevent HCC development involves inhibiting HBV replication, 
reducing the viral load in serum, and accelerating seroconversion of hepatitis $\mathrm{B}$ e antigen ( $\mathrm{HBeAg}$ ) to improve liver function. Anti-HBV treatment is also important for patients with HBV-related HCC because it can reduce/ delay HCC recurrence and prolong their survival. ${ }^{3-5}$ Therefore, it is worth paying attention to adherence to antiviral therapy in patients with HBV-related HCC. It has been reported that low adherence to NUC treatment increases the risk of virological failure. ${ }^{6-9}$ Hence, it is important to ensure that patients take nucleos $(\mathrm{t})$ ide analogs (NUCs) appropriately and regularly to maintain undetectable HBV DNA levels.

In recent years, several studies have reported adherence to antiviral treatment in patients with chronic hepatitis $\mathrm{B}(\mathrm{CHB}),{ }^{7-14}$ and the mean prevalence of adherence to various NUCs ranged from 53.6 to $99 \% .^{8-12}$ Four studies reported the mean prevalence of adherence to various NUCs of $100 \%$. $^{7,10,13,14}$ Previously, a common definition of adherence to antiviral treatment has been absent, and different methods (eg, self-reporting, pharmacy refill claims, pill count, measuring the drug level in plasma) have been employed for adherence assessment. ${ }^{7-14}$ Sociodemographic, clinical, and psychological variables have been found to be related to higher adherence to NUC use: older age, high income, a history of NUC treatment, and use of NUCs other than lamivudine (LAM). ${ }^{7-14}$ Due to different evaluation methods and different geographic regions of patients, the related variables were very different in those studies, and none were related with each other consistently in any study. A study assessing adherence to NUC use in patients with HBV-related $\mathrm{HCC}$ is lacking.

The aims of the present study were to investigate the: (i) adherence to NUC treatment in patients with HBVrelated HCC in China; (ii) demographic, clinical, and patient-knowledge factors related to non-adherence; (iii) correlation between adherence to NUCs and viral breakthrough (VBT) in patients with HBV-related HCC.

\section{Patients and Methods}

\section{Ethical Approval of the Study Protocol}

This study was carried out in accordance with the principles of the Declaration of Helsinki 1964 and its later amendments. The study protocol was approved (EHBHKY2020-02-007) by the Ethics Committee of Eastern Hepatobiliary Surgery Hospital within Second Military Medical University (Shanghai, China). Written informed consent was obtained from each participant. The registration number for this clinical study is ChiCTR2000037888.

\section{Inclusion and Exclusion Criteria}

The inclusion criteria were patients: (i) diagnosed as having HBV-related HCC and taking at least one type of NUC for CHB treatment; (ii) aged $\geq 18$ years; (iii) who understood and agreed to the objectives and methodology of our study.

The exclusion criteria were patients: (i) suffering from co-infection with another type of hepatitis virus (C or D); (ii) infected with the human immunodeficiency virus; (iii) with decompensated liver disease; (iv) who have not been told the truth about their condition; (v) who were pregnant; (vi) who required a caregiver to help them take medicines or had a cognitive impairment which stopped them understanding the study questionnaire.

\section{Participants}

A single-center cross-sectional study was designed and conducted at Eastern Hepatobiliary Surgery Hospital from August 2020 to February 2021. Study participants were hospitalized patients with HBV-related HCC. Patients received resection, radiofrequency ablation, transcatheter arterial chemoembolization, radiotherapy, or molecular-targeted therapies. The interview was conducted when patients were first hospitalized.

\section{Data Collection}

A structured questionnaire was used to interview patients for collecting information (socioeconomic, demographic, psychological characteristics, knowledge about pharmacologic treatment). The clinical profile was obtained by browsing electronic medical records and asking patients. Each electronic medical record was scanned to obtain information on medical history, previous and current HBV treatments, and virological response.

Demographic variables were age, sex, tobacco smoking, and alcohol consumption. Socioeconomic variables were occupation, marital status, education level, monthly per capita income, and type of medical insurance. Clinical variables were: a family history of liver disease; duration of known HBV infection; time of diagnosis of HCC; HCC recurrence; comorbidity; duration of current HBV treatment; current HBV medication; previous HBV treatment; HBeAg level; alanine aminotransferase (ALT) level. Variables on patients' knowledge of anti-HBV treatment 
were whether they knew their result of $\mathrm{HBeAg}$ testing (positive or negative), HBV DNA level (positive or negative) and ALT level (increased or normal), the reason for treatment, and harm of treatment cessation.

Psychological characteristics were assessed by the Hospital Anxiety and Depression Scale (HADS). HADS (which is used commonly in assessment of the psychological status of cancer patients) is a scale for determining the levels of depression and anxiety that a patient is experiencing. ${ }^{15,16}$ It consists of 14 items: the depression scale and anxiety scale account for seven items, respectively. Each item is scored from 0 to 3 according to severity of experiencing difficulties, so a person can score between 0 and 21 for anxiety or depression. A score between 0 to 7,8 to 10 , and 11 to 21 represents "no case", "possible case", and "probable case" of anxiety/ depression, respectively. A review of the HADS has reported good validity in chronic-illness groups, with Cronbach's alpha for the anxiety scale varying from 0.68 to 0.93 (mean, 0.83 ) and the depression scale varying from 0.67 to 0.90 (mean, 0.82). ${ }^{17}$

VBT is the first manifestation of antiviral drug resistance during anti-HBV treatment. VBT was defined as an increase in serum HBV DNA $\geq 1 \log _{10}$ above the nadir or 10 -times the limit of detection in patients who had undetectable HBV DNA previously. HBV DNA was rechecked upon hospital admission for all patients with HBV-related HCC. Real-time reverse transcription-quantitative polymerase chain reaction was used to measure the serum level of HBV DNA. VBT patients who experienced antiviral drug-resistance and whose drug regimen was altered were advised to undergo testing for antiviral drug-resistant strains with mutations, which was determined by direct sequencing.

\section{Adherence Measures}

A visual analog scale that ranged from 0 to 10 for overall adherence to taking NUCs over the past 30 days was employed: " 0 " for taking no medication and " 10 " for taking all of the prescribed medications. "High adherence" was defined as self-graded adherence $>9$, whereas $\leq 9$ was classed as "low adherence".

\section{Statistical Analyses}

Continuous variables and categorical variables are expressed as the mean $\pm \mathrm{SD}$ and number (percentage), respectively. The data of the adherent group and non-adherent group were compared using Student's $t$-test for continuous variables and the chi-square test for categorical variables.
Multivariate logistic regression analysis was employed to explore independent risk factors that affected adherence behavior. Variables with $\mathrm{P}<0.05$ in the univariate analysis were entered into a logistic regression model. SPSS 21.0 (IBM, Armonk, NY, USA) was used for statistical analyses.

\section{Results}

Two-hundred and forty-five consecutive inpatients with HBVrelated HCC receiving NUCs were invited to participate, and $227(92.7 \%)$ of patients agreed to take part in our study. Fortysix patients were excluded and, eventually, 181 patients completed the study. The reasons for exclusion were patients: did not complete the questionnaire because they did not want to disclose private information $(n=27)$; required a caregiver to administer their medicines $(n=8)$; who had not been told the truth about their condition $(n=6)$; coinfected with the hepatitis $\mathrm{C}$ virus ( $\mathrm{HCV} ; \mathrm{n}=5)$.

\section{Characteristics of Patients at Baseline}

One-hundred and eighty-one patients formed the study cohort, of which $81.2 \%$ of patients were men. The mean age was 54.07 years \pm 11.26 years. Also, $41.4 \%$ of patients were farmers. In addition, $63.0 \%$ of patients did not achieve middle-school education, and $65.2 \%$ reported a monthly per capita income less than $¥ 5000$ (Table 1). Patients with a low level of education and low-income accounted for a large proportion of our study cohort.

Table 2 shows the clinical variables of patients and compares the differences between the adherent group and nonadherent group. In 141 (77.9\%) patients, HBV infection had been present $>5$ years, and $\mathrm{HCC}$ had been diagnosed in the past 6 months in $113(62.4 \%)$ patients. One-hundred and sixty (88.4\%) patients received NUC monotherapy, among which entecavir (ETV) was the most prescribed (66.9\%). In addition, 21 patients received two NUCs, of which combination therapy of ETV and adefovir dipivoxil was the most prevalent $(6.1 \%)$. Fifty-nine $(32.6 \%)$ patients had taken medication for $\mathrm{HBV}$ infection for $\leq 6$ months, whereas $96(53.0 \%)$ patients had taken medication for HBV infection for $>2$ years. Sixty-five $(35.9 \%)$ patients had altered the anti-HBV drugs they had been taking previously.

According to our interview (Table 3), patients' knowledge of pharmacologic treatment of $\mathrm{CHB}$ was poor. The proportion of patients who were aware of their $\mathrm{HBeAg}$ status (positive or negative), titer of HBV DNA (positive or negative), and ALT level (increased or normal) was $64.1 \%, 48.1 \%$, and $47.5 \%$ respectively. Only $38.1 \%$ of patients were aware of the reason for anti-HBV treatment 
Table I Correlation Between Patients' Socioeconomic Demographic Variables and Adherence to Nucleos(t)ide Analogues in Hepatitis B Virus Related Hepatocellular Carcinoma Patients

\begin{tabular}{|c|c|c|c|c|}
\hline Characteristics & Descriptives $(n=|8|)$ & Non-Adherent $(n=97)$ & Adherent $(n=84)$ & $P$-value \\
\hline \multicolumn{5}{|l|}{ Sex, n (\%) } \\
\hline Male & $147(8 \mid .2)$ & $85(87.6)$ & $62(73.8)$ & 0.018 \\
\hline Female & $34(18.8)$ & $12(12.4)$ & $22(26.2)$ & \\
\hline Age (years) (mean $\pm S D)$ & $54.07 \pm 11.26$ & $55.04 \pm 11.67$ & $52.95 \pm 10.72$ & 0.214 \\
\hline \multicolumn{5}{|l|}{ Occupation, n (\%) } \\
\hline Farmers & $75(4 \mid .4)$ & $38(39.2)$ & $37(44.0)$ & 0.296 \\
\hline Employed & $62(34.3)$ & $30(30.9)$ & $32(38.1)$ & \\
\hline Retired & $28(15.5)$ & $18(18.6)$ & $10(11.9)$ & \\
\hline Homemaker & $16(8.8)$ & II (II.3) & $5(6.0)$ & \\
\hline \multicolumn{5}{|l|}{ Marital status, n (\%) } \\
\hline Married & $166(91.7)$ & 87 (89.7) & $79(94.0)$ & 0.289 \\
\hline Other marital status & $15(8.3)$ & $10(10.3)$ & $5(6.0)$ & \\
\hline \multicolumn{5}{|l|}{ Education levels, n (\%) } \\
\hline Elementary school (0-6 years) & $22(12.2)$ & II (II.3) & II (I3.I) & 0.927 \\
\hline Secondary (7-10 years) & $92(50.8)$ & $48(49.5)$ & $44(52.4)$ & \\
\hline High school (10-12years) & $49(27.1)$ & $28(28.9)$ & $21(25.0)$ & \\
\hline Higher (>12years) & $18(9.9)$ & $10(10.3)$ & $8(9.5)$ & \\
\hline \multicolumn{5}{|l|}{ Monthly per capita income, n (\%) } \\
\hline$<2000$ yuan & $50(27.6)$ & $24(24.7)$ & $26(31.0)$ & 0.130 \\
\hline $2000-5000$ yuan & $68(37.6)$ & $43(44.3)$ & $25(29.8)$ & \\
\hline$>5000$ yuan & $63(34.8)$ & $30(30.9)$ & $33(39.3)$ & \\
\hline \multicolumn{5}{|l|}{ Type of medical insurance, n (\%) } \\
\hline Self-pay & $26(14.4)$ & $9(9.3)$ & $17(20.2)$ & 0.135 \\
\hline Rural Cooperative Medical Insurance & $72(39.8)$ & $39(40.2)$ & $33(39.3)$ & \\
\hline With basic medical insurance & $76(42.0)$ & $46(47.4)$ & $30(35.7)$ & \\
\hline Free medical care & $7(3.9)$ & $3(3.1)$ & $4(4.8)$ & \\
\hline \multicolumn{5}{|l|}{ Family history of hepatopathy, $\mathrm{n}(\%)$} \\
\hline Yes & $93(51.4)$ & $53(54.6)$ & $40(47.6)$ & 0.346 \\
\hline No & $88(48.6)$ & $44(45.4)$ & $44(52.4)$ & \\
\hline \multicolumn{5}{|l|}{ Tobacco use, n (\%) } \\
\hline Yes & $60(33.1)$ & $33(34.0)$ & $27(32.1)$ & 0.789 \\
\hline No & $121(66.9)$ & $64(66.0)$ & $57(67.9)$ & \\
\hline \multicolumn{5}{|l|}{ Alcohol use, n (\%) } \\
\hline Yes & $36(19.9)$ & $26(26.8)$ & $10(11.9)$ & 0.012 \\
\hline No & $145(80.1)$ & $7 \mid(73.2)$ & $74(88.1)$ & \\
\hline
\end{tabular}

for HBV-related HCC, and $56.9 \%$ of patients realized the harm of treatment cessation. Table 3 details the numbers of patients with each level of anxiety and depression in HADS. The proportion of patients with anxiety and depression was $30.4 \%$ and $39.2 \%$, respectively (score $>8$ was used to define anxiety and depression).

\section{Adherence to Anti-HBV Medication}

High adherence was reported in $46.4 \%$ of patients with HBV-related HCC. The most common reasons for failure to take anti-HBV medication on time were forgetfulness (n $=34)$, financial issues $(\mathrm{n}=26)$ and stopping taking the drug when feeling better $(\mathrm{n}=21)$. 
Table 2 Correlation Between Patients' Clinical Profile and Adherence to Nucleos(t)ide Analogues in Hepatitis B Virus Related Hepatocellular Carcinoma Patients

\begin{tabular}{|c|c|c|c|c|}
\hline Characteristics & Descriptives $(n=|8|)$ & Non-Adherent $(n=97)$ & Adherent $(n=84)$ & $p$-value \\
\hline $\begin{array}{l}\text { Duration of known HBV infection } \\
>5 \text { years } \\
\text { I-5 years } \\
<1 \text { year }\end{array}$ & $\begin{array}{l}|4|(77.9) \\
17(9.4) \\
23(12.7)\end{array}$ & $\begin{array}{l}79(81.4) \\
8(8.2) \\
10(10.3)\end{array}$ & $\begin{array}{l}62(73.8) \\
9(10.7) \\
13(15.5)\end{array}$ & 0.455 \\
\hline $\begin{array}{l}\text { Time of diagnosis of HCC } \\
<\text { six months } \\
\text { >six months }\end{array}$ & $\begin{array}{l}\text { II }(62.4) \\
68(37.6)\end{array}$ & $\begin{array}{l}56(57.7) \\
4 \mid(42.3)\end{array}$ & $\begin{array}{l}57(67.9) \\
27(32.1)\end{array}$ & 0.161 \\
\hline $\begin{array}{l}\text { HCC recurrence } \\
\text { First recurrence } \\
\text { Multiple recurrence } \\
\text { No }\end{array}$ & $\begin{array}{l}38(21.0) \\
14(7.7) \\
129(7 \mid .3)\end{array}$ & $\begin{aligned} 22 & (22.7) \\
8 & (8.2) \\
67 & (69.1)\end{aligned}$ & $\begin{aligned} 16 & (19.0) \\
6 & (7.1) \\
62 & (73.8)\end{aligned}$ & 0.496 \\
\hline $\begin{array}{l}\text { Comorbid conditions } \\
\text { Yes } \\
\text { No }\end{array}$ & $\begin{array}{c}72(39.8) \\
109(30.2)\end{array}$ & $\begin{array}{l}39(40.2) \\
58(59.8)\end{array}$ & $\begin{array}{l}33(39.3) \\
5 I(60.7)\end{array}$ & 0.900 \\
\hline $\begin{array}{l}\text { Current HBV medication } \\
\text { Entecavir } \\
\text { Other NUCs } \\
\text { Combination use of two drugs }\end{array}$ & $\begin{array}{l}121(66.9) \\
39(21.5) \\
21(11.6)\end{array}$ & $\begin{array}{c}73(75.3) \\
16(16.5) \\
8(8.2)\end{array}$ & $\begin{array}{l}48(57.1) \\
23(27.3) \\
13(15.5)\end{array}$ & 0.035 \\
\hline $\begin{array}{l}\text { Duration of current HBV treatment } \\
<6 \text { months } \\
6 \text { months-2years } \\
>2 \text { years }\end{array}$ & $\begin{array}{l}59(32.6) \\
26(14.4) \\
96(53.0)\end{array}$ & $\begin{array}{l}29(29.9) \\
11(11.3) \\
57(58.8)\end{array}$ & $\begin{array}{l}30(35.7) \\
15(17.9) \\
39(46.4)\end{array}$ & 0.213 \\
\hline $\begin{array}{l}\text { Previous HBV treatment } \\
\text { Yes } \\
\text { No }\end{array}$ & $\begin{array}{c}65(35.9) \\
116(64.1)\end{array}$ & $\begin{array}{l}37(38.1) \\
60(61.9)\end{array}$ & $\begin{array}{l}28(33.3) \\
56(66.7)\end{array}$ & 0.501 \\
\hline $\begin{array}{l}\text { Elevated ALT } \\
\text { Yes } \\
\text { No }\end{array}$ & $\begin{array}{c}24(13.3) \\
157(86.7)\end{array}$ & $\begin{array}{l}15(15.5) \\
82(84.5)\end{array}$ & $\begin{array}{c}9(10.7) \\
75(89.3)\end{array}$ & 0.347 \\
\hline $\begin{array}{l}\mathrm{HBeAg} \\
\text { Positive } \\
\text { Negative }\end{array}$ & $\begin{array}{c}68(37.6) \\
113(62.4)\end{array}$ & $\begin{array}{l}33(34.0) \\
64(66.0)\end{array}$ & $\begin{array}{l}35(4 I .7) \\
49(58.3)\end{array}$ & 0.289 \\
\hline
\end{tabular}

Abbreviations: $\mathrm{HBV}$, hepatitis B virus; $\mathrm{HCC}$, hepatocellular carcinoma; NUCs, nucleos(t)ide analogues; ALT, alanine aminotransferase; $\mathrm{HBeAg}$, hepatitis B e antigen.

\section{Factors Associated with High Adherence}

Univariate analysis suggested that adherence with NUC treatment was associated significantly with sex $(\mathrm{P}=$ 0.018), alcohol consumption $(\mathrm{P}=0.012)$, types of antiHBV medication being taken $(\mathrm{P}=0.035)$, and whether the patient knew his/her HBV DNA level $(\mathrm{P}=0.048)$. Highadherence patients were more likely to be women, nonconsumers of alcohol, taking NUCs other than ETV, and who paid attention to the result of HBV DNA testing.
Other variables did not carry a significant difference between the two groups (Tables 1-3).

\section{Logistic Regression Analysis}

Logistic regression analysis was used to investigate the predictors of medication non-adherence. Variables with $\mathrm{P}<0.05$ in the univariate analysis were included in the logistic regression model. Logistic regression analysis showed that sex (odds ratio (OR) 2.123, $\mathrm{P}=0.06$ ), 
Table 3 Correlation Between Patients' Knowledge About Medication Treatment as Well as Psychological Factors and Adherence to Nucleos(t)ide Analogues in Hepatitis B Virus Related Hepatocellular Carcinoma Patients

\begin{tabular}{|c|c|c|c|c|}
\hline Characteristics & $\begin{array}{c}\text { Descriptives } \\
(n=|8|)\end{array}$ & $\begin{array}{l}\text { Non-Adherent } \\
(n=97)\end{array}$ & $\begin{array}{c}\text { Adherent } \\
(n=84)\end{array}$ & $p$-value \\
\hline \multicolumn{5}{|c|}{ Patient is aware of $\mathrm{HBeAg}$ test results } \\
\hline Yes & $116(64.1)$ & $63(64.9)$ & $53(63.1)$ & 0.795 \\
\hline No & $65(35.9)$ & $34(35.1)$ & $31(36.9)$ & \\
\hline \multicolumn{5}{|c|}{ Patient is aware of titer of HBV DNA } \\
\hline Yes & $87(48.1)$ & $40(4 I .2)$ & $47(56.0)$ & 0.048 \\
\hline No & $94(51.9)$ & $57(58.8)$ & $37(44.0)$ & \\
\hline \multicolumn{5}{|c|}{ Patient is aware of ALT level } \\
\hline Yes & $86(47.5)$ & $43(44.3)$ & $43(5 \mid .2)$ & 0.357 \\
\hline No & $95(52.5)$ & $54(55.7)$ & $4 \mathrm{I}(48.8)$ & \\
\hline \multicolumn{5}{|c|}{ Patient is aware of the reason of treatment } \\
\hline Yes & $69(38.1)$ & $36(37.1)$ & $33(39.3)$ & 0.871 \\
\hline Patially know & $53(29.3)$ & $30(30.9)$ & $23(27.4)$ & \\
\hline No & $59(32.6)$ & $31(32.0)$ & $28(33.3)$ & \\
\hline \multicolumn{5}{|c|}{ Patient is aware of the harm of cessation of treatment } \\
\hline Yes & $103(56.9)$ & $54(55.7)$ & $49(58.3)$ & 0.718 \\
\hline No & $78(43.1)$ & $43(44.3)$ & $35(4 I .7)$ & \\
\hline \multicolumn{5}{|l|}{ HADS anxiety } \\
\hline No case & $126(69.6)$ & $66(68.0)$ & $60(71.4)$ & 0.814 \\
\hline Possible case & $35(19.3)$ & $19(19.6)$ & $16(19.0)$ & \\
\hline Probable case & $20(11.0)$ & $12(12.4)$ & $8(9.5)$ & \\
\hline \multicolumn{5}{|l|}{ HADS depression } \\
\hline No case & $110(60.8)$ & $58(59.8)$ & $52(61.9)$ & 0.490 \\
\hline Possible case & $43(23.8)$ & $26(26.8)$ & $17(20.2)$ & \\
\hline Probable case & $28(15.5)$ & $13(13.4)$ & $15(17.9)$ & \\
\hline
\end{tabular}

Abbreviations: $\mathrm{HBeAg}$, hepatitis B e antigen; HBV, hepatitis B virus; ALT, alanine aminotransferase; HADS, The Hospital Anxiety and Depression Scale.

consuming alcohol (OR 2.380, $\mathrm{P}=0.04)$, and taking ETV (OR 1.613, $\mathrm{P}=0.04)$ were predictors of medication nonadherence (Table 4).

\section{Correlation Between Medication Adherence and VBT}

One-hundred and eighteen patients had been taking NUCs $>6$ months and who had achieved a virological response (undetectable HBV DNA in serum) in previous treatment. Of these, 16 of $65(24.6 \%)$ patients with non-adherence and nine of $53(17.0 \%)$ patients with high adherence developed VBT $(\mathrm{P}=0.31)$. Among the 25 VBT patients, 17 patients were receiving ETV and 11 patients had altered their medication. Through direct sequencing, four patients were identified as having antiviral drug-resistant strains with mutations.

\section{Discussion}

A "gold standard" method to measure adherence to taking antiviral drugs is not available. In recent years, several studies have been conducted on adherence to antiviral treatment for CHB using self-reporting, pill count, pharmacy refill claims, and measuring the drug level in plasma. $^{7-14}$ It is more accurate to evaluate the adherence of patients to medication by pill counting and analysis of electronic prescriptions. For example, Manolakopoulos et $\mathrm{al}^{11}$ used retrospective analysis of electronic prescription data to investigate the medication adherence of HBV patients in Greece. Self-reporting is a simple and inexpensive method to measure medication adherence, but adherence based on self-reporting may give inaccurate data. Chotiyaputta et $\mathrm{al}^{8}$ used questionnaires to investigate the medication adherence of patients with CHB. The patients 
Table 4 Logistic Regression Analysis of Demographic, Clinical and Knowledge Characteristics in Relation to Adherence

\begin{tabular}{|l|c|c|c|c|c|c|}
\hline & Variables & Beta & SE & P-value & Exp (B) & (95\% CI) \\
\hline \multirow{2}{*}{ StepI } & Sex & 0.774 & 0.411 & 0.060 & 2.168 & $0.968,4.853$ \\
& Drinking & 0.820 & 0.418 & 0.050 & 2.271 & $1.001,5.154$ \\
& Current HBV medication & 0.444 & 0.235 & 0.058 & 1.559 & $0.984,2.469$ \\
& Patient is aware of HBV DNA level & 0.492 & 0.315 & 0.118 & 1.636 & $0.882,3.033$ \\
\hline \multirow{2}{*}{ Step2 } & Sex & 0.753 & 0.406 & 0.064 & 2.123 & $0.957,4.709$ \\
& Drinking & 0.867 & 0.417 & 0.038 & 2.380 & $1.050,5.393$ \\
& Current HBV medication & 0.478 & 0.231 & 0.038 & 1.613 & $1.026,2.537$ \\
\hline
\end{tabular}

Abbreviation: HBV, hepatitis B virus.

we interviewed arose from different provinces and cities in China. After treatment of HCC in Shanghai, they returned to their residence, so maintaining contact with them for a long time was challenging. Therefore, we could not choose the survey methods needed to follow-up patients. A cross-sectional study using questionnaires appeared to be a better choice for our study. Our respondents were cancer patients and most of them had a low education level, so a questionnaire with a complex structure or which was time-consuming was not suitable for our study cohort. Therefore, we chose a simple and clear visual analog scale (VAS) to evaluate the adherence of patients to medication. A VAS has been demonstrated to be a reliable option for assessing the adherence of patients to taking antiviral drugs. ${ }^{18-20}$

Patients with high adherence (self-graded adherence $>9$ ) accounted for $46.4 \%$ of patients in the present study. According to studies conducted in China and other countries, the prevalence of adherence to NUC therapy in CHB patients ranges from $53.6 \%$ to $99 \%$, and that for selfreporting of adherence to NUC therapy varies from $53.6 \%$ to $84 \%{ }^{7-14}$ It appears that low adherence to medication occurs more frequently in patients with HBVrelated HCC than that in CHB patients. According to our interviews with patients with low adherence, in addition to forgetfulness, economic reasons and feeling better were the main reasons patients did not take medication on time and regularly. According to statistical analyses, the income of patients was not a risk factor for low adherence, but some patients did not take their medication on time due to economic reasons. In addition, some patients did not take their medication on time or stopped taking their medication because they felt better. These actions may have been because some patients: (i) thought that taking their medication on time was no longer important because they had achieved a virological response; (ii) did not know their status of HBV control or how long they need to take NUCs. These actions may have been related to insufficient explanation of the patient's condition and education on medication by medical staff. In addition to explaining the necessity and beneficial effect of antiviral therapy to patients at the initial stage of treatment, physicians must also explain the current status of HBV control and the importance of continued medication-taking during followup treatment and re-examination. The reason for the lower adherence of patients with HBV-related HCC with antiviral therapy compared with that in CHB patients is not clear: whether it is related to the occurrence and recurrence of HCC merits further exploration.

High-adherence patients were more likely to be women, to shun alcohol, take NUCs other than ETV, and to pay attention to their result for HBV DNA testing. Studies in CHB patients have reported sex and current HBV medication to be associated with medication adherence. , $^{8,10,12}$ Several studies have shown that the adherence of women to medications is higher than that of men. ${ }^{21-23}$ Peng et al ${ }^{12}$ reported that female CHB patients showed higher adherence to NUC treatment than that of males in a Chinese population: those data are in accordance with our results. However, Chotiyaputta et $\mathrm{al}^{8}$ found that male CHB patients showed higher adherence to their drug regimen than female CHB patients. Such differing results may be due to cultural differences between China and the West.

In the present study, patients receiving ETV showed lower adherence compared with those taking other NUCs. Peng et $\mathrm{al}^{11,12}$ found that those who took LAM or ETV showed lower medication adherence than patients taking telbivudine. Chotiyaputta et $\mathrm{al}^{10}$ reported that people in receipt of NUCs other than LAM were more likely to have a prevalence of adherence $>90 \%$. In our study, most patients were taking ETV $(\mathrm{n}=121,66.9 \%)$, including 34 patients who were taking other NUCs originally and who 
then switched to ETV. The lower adherence of patients receiving ETV may have been because the high efficiency and high barrier for development of viral resistance of ETV made some patients neglect the importance of taking their medication on time.

We report, for the first time, that patients that did not consume alcohol and who were aware of their HBV DNA titer had higher medication adherence. van Vlerken et $\mathrm{al}^{13}$ found that alcohol consumption was not related to adherence to ETV treatment in CHB patients. Anand et $\mathrm{al}^{24}$ investigated the relationship between alcohol consumption and HCV treatment. They found that recent consumption of alcohol was related to increased interruption of treatment and a lower sustained virologic response. In our study, "alcohol drinkers" referred to patients who consumed $\geq 1$ alcoholic beverage per day. All HCC patients who were alcohol drinkers were counseled by their physicians to cease alcohol consumption, but some could not quit this addiction. Patients who refused advice on alcohol abstinence were more likely to have low adherence to NUC use.

According to our interview, $48.1 \%$ and $47.5 \%$ of patients were aware of their HBV DNA titer (positive or negative) and ALT level, respectively. Besides, $61.9 \%$ and $43.1 \%$ of patients did not know the reason for anti-HBV treatment and the harm of treatment cessation (Table 3). The inadequate supply of medical resources in China has led to a general lack of education on medication for patients. We showed that being aware of the test result of HBV DNA had a positive influence on adherence to prescribed therapy. Medical staff should spend more time explaining to patients the current control of $\mathrm{CHB}$ and importance of adherence to NUC therapy. Under the pressure of huge numbers of patients, we could educate patients more effectively using the Internet or social media (eg, WeChat ${ }^{\mathrm{TM}}$ ). Logistic regression analysis showed that predictors of non-adherence to NUC treatment were being male, an alcohol drinker, and taking ETV. Therefore, we may need to pay more attention to the medication adherence of such patients.

We found that VBT prevalence was lower in patients who adhered to NUC therapy than in those who did not, but the difference was not significant $(\mathrm{P}=0.31)$. Several HBV studies have demonstrated the virological response of medication-adherent patients to be stronger than that of non-medication-adherent patients, and for some of the differences to be significant. ${ }^{6-9}$ One view is that poor adherence to antiviral drugs may be a more important factor in treatment failure than antiviral resistance, especially if patients are taking new anti-HBV agents, including ETV and tenofovir. ${ }^{25,26}$ Accordingly, we should educate patients on adhering to anti-HBV therapy. In addition, it is necessary to confirm VBT by retesting serum HBV DNA and/or confirming genotypic resistance before altering treatment.

Our study had three main limitations. First, the study cohort was small. Second, all patients were from one center. Third, the method used to evaluate adherence to anti-HBV therapy was subjective.

The influence of HCC on the adherence of patients to anti-HBV therapy merits more detailed and extensive research. Nevertheless, for the first time, we evaluated the adherence of patients with HBV-related HCC to NUC therapy. Our results could provide useful information for improvement of therapy for HBV-related HCC.

\section{Conclusions}

High adherence to NUC therapy was reported in $46.4 \%$ of patients with HBV-related HCC. Being male, an alcohol drinker, and taking ETV were independent risk factors for low adherence to anti-HBV therapy $(\mathrm{P}<0.05)$. VBT prevalence was lower in patients who adhered to NUC therapy than those who did not, but the difference was not significant $(P=0.31)$. The low prevalence of medication adherence of patients with HBV-related HCC may be related to insufficient explanation of HBVrelated $\mathrm{HCC}$ and medication education by medical staff. Medical staff should not only explain the current status of CHB control and the importance of adherence to NUC therapy to patients at the early stage of treatment, but also during follow-up treatment and reexamination. How to carry out medication education for patients more effectively is worthy of further exploration. Our study could help patients with HBVrelated HCC to pay more attention to adherence to antiviral therapy, and provide a reference for improving the efficacy of antiviral therapy in patients with HBV-related HCC.

\section{Data Sharing Statement}

The data that support the findings of this study are available from the corresponding author upon reasonable request from 3 months to 36 months following article publication. 


\section{Acknowledgments}

The authors thank Jun Chen, Bin Zhang, Xinxia Wang and Qi Zhan. Although they did not participate directly in this study, their work in another study helped us to carry out this study smoothly. We thank all the patients who participated in this study.

\section{Author Contributions}

All authors made a significant contribution to the work reported, whether that is in the conception, study design, execution, acquisition of data, analysis and interpretation, or in all these areas; took part in drafting, revising or critically reviewing the article; gave final approval of the version to be published; have agreed on the journal to which the article has been submitted; and agree to be accountable for all aspects of the work.

\section{Funding}

This study was supported by Seed Founding of Shanghai Ninth People's Hospital, Shanghai JiaoTong University School of Medicine (JYZZ063), Shanghai "Rising Stars of Medical Talents" Youth Development Program-Youth Medical Talents: Clinical Pharmacist Program (SHWSRS (2021)_099).

\section{Disclosure}

The authors report no conflicts of interest in this work.

\section{References}

1. Chen WQ, Sun KX, Zheng RS, et al. Cancer incidence and mortality in China, 2014. Chin J Cancer Res. 2018;30(1):1-12. doi:10.21147/j. issn.1000-9604.2018.01.01

2. Nguyen VT, Law MG, Dore GJ. Hepatitis B-related hepatocellular carcinoma: epidemiological characteristics and disease burden. J Viral Hepat. 2009;16:453-463. doi:10.1111/j.1365-2893.2009.01117.x

3. Herbst DA, Reddy KR. Risk factors for hepatocellular carcinoma. Clin Liver Dis. 2012;1:180-182. doi:10.1002/cld.111

4. El-Serag HB. Epidemiology of viral hepatitis and hepatocellular carcinoma. Gastroenterology. 2012;142:1264-1273. doi:10.1053/j. gastro.2011.12.061

5. Arzumanyan A, Reis HM, Feitelson MA. Pathogenic mechanisms in HBV- and HCV-associated hepatocellular carcinoma. Nat Rev Cancer. 2013;13:123-135. doi:10.1038/nrc3449

6. Hilleret MN, Larrat S, Stanke-Labesque F, Leroy V. Does adherence to hepatitis B antiviral treatment correlate with virological response and risk of breakthrough? J Hepatol. 2011;55:1468-1469. doi:10.1016/j.jhep.2011.04.006

7. Sogni P, Carrieri MP, Fontaine $\mathrm{H}$, et al. The role of adherence in virological suppression in patients receiving anti-HBV analogues. Antivir Ther. 2012;17:395-400. doi:10.3851/IMP1944

8. Chotiyaputta W, Hongthanakorn C, Oberhelman K, Fontana RJ, Licari T, Lok AS. Adherence to nucleos(t)ide analogues for chronic hepatitis B in clinical practice and correlation with virological breakthroughs (VBT). J Viral Hepat. 2012;19:205-212. doi:10.1111/j.13652893.2011.01494.x
9. Berg T, Marcellin P, Zoulim F, et al. Tenofovir is effective alone or with emtricitabine in adefovir-treated patients with chronic-hepatitis B virus infection. Gastroenterology. 2010;139:1207-1217. doi:10.1053/j.gastro.2010.06.053

10. Chotiyaputta W, Peterson C, Ditah FA, Goodwin D, Lok AS. Persistence and adherence to nucleos(t)ide analogue treatment for chronic hepatitis B. J Hepatol. 2011;54:12-18. doi:10.1016/j. jhep.2010.06.016

11. Manolakopoulos S, Striki A, Papastergiou V, et al. Persistence and adherence to nucleos(t)ide analogues in chronic hepatitis B: a multicenter cohort study. Eur J Gastroenterol Hepatol. 2020;32 (5):635-641. doi:10.1097/MEG.0000000000001558

12. Peng J, Yin JH, Cai SH. Factors associated with adherence to nucleos(t)ide analogs in chronic hepatitis B patients: results from a 1-year follow-up study. Patient Prefer Adherence. 2015;9:41-45. doi:10.2147/PPA.S71510

13. van Vlerken LG, Arends P, Lieveld FI, et al. Real life adherence of chronic hepatitis B patients to entecavir treatment. Digest Liver Dis. 2015;47:577-583. doi:10.1016/j.dld.2015.03.024

14. Giang L, Selinger CP, Lee AU. Evaluation of adherence to oral antiviral hepatitis B treatment using structured questionnaires. World J Hepatol. 2012;4:43-49. doi:10.4254/wjh.v4.i2.43

15. Hirai K, Shiozaki M, Motooka H, et al. Discrimination between worry and anxiety among cancer patients: development of a brief cancer-related worry inventory. Psychooncology. 2008;17:1172-1179. doi:10.1002/pon.1348

16. Mackenzie LJ, Carey ML, Sanson-Fisher RW, D’Este CA, Paul CL, Yoong SL. Agreement between HADS classifications and single-item screening questions for anxiety and depression: a cross-sectional survey of cancer patients. Ann Oncol. 2014;25:889-895. doi:10.1093/annonc/mdu023

17. Bjelland I, Dahl AA, Haug TT, Neckelmann D. The validity of the hospital anxiety and depression scale: an updated literature review. J Pyschosom Res. 2002;52:69-77. doi:10.1016/S0022-3999(01)00296-3

18. Pericot-Valverde I, Rennert L, Heo M, et al. Rates of perfect self-reported adherence to direct-acting antiviral therapy and its correlates among people who inject drugs on medications for opioid use disorder: the PREVAIL study. J Viral Hepat. 2021;28(3):548-557. doi:10.1111/jvh.13445

19. Zhang Q, Li X, Qiao S, Shen Z, Zhou Y. Comparing self-reported medication adherence measures with hair antiretroviral concentration among people living with HIV in Guangxi, China. AIDS Res Ther. 2020;17(1):8. doi:10.1186/s12981-020-00265-4

20. Burton MJ, Voluse AC, Patel AB, Konkle-Parker D. Measuring adherence to hepatitis $\mathrm{C}$ direct-acting antiviral medications: using the VAS in an HCV treatment clinic. South Med J. 2018;111 (1):45-50. doi:10.14423/SMJ.0000000000000750

21. Caro JJ, Salas M, Speckman JL, Raggio G, Jackson JD. Persistence with treatment for hypertension in actual practice. CMAJ. 1999;160:31-37.

22. Marentette MA, Gerth WC, Billings DK, Zarnke KB. Antihypertensive persistence and drug class. Can J Cardiol. 2002;18:649-656.

23. Kane SV, Cohen RD, Aikens JE, Hanauer SB. Prevalence of nonadherence with maintenance mesalaminein quiescent ulcerative colitis. Am J Gastroenterol. 2001;96:2929-2933. doi:10.1111/ j.1572-0241.2001.04683.x

24. Anand BS, Currie S, Dieperink E, et al. Alcohol use and treatment of hepatitis $\mathrm{C}$ virus: results of a national multicenter study. Gastroenterology. 2006;130:1607-1616. doi:10.1053/j.gastro.2006.02.023

25. Ha NB, Ha NB, Garcia RT, et al. Medication nonadherence with long-term management of patients with hepatitis B e antigen-negative chronic hepatitis B. Dig Dis Sci. 2011;56:2423-2431. doi:10.1007/ s10620-011-1610-5

26. Kamezaki H, Kanda T, Arai M, et al. Adherence to medication is a more important contributor to viral breakthrough in chronic hepatitis B patients treated with ETV than in those with lamivudine. Int J Med Sci. 2013;10:567-574. doi:10.7150/ijms.5795 


\section{Publish your work in this journal}

Patient Preference and Adherence is an international, peer-reviewed, open access journal that focusing on the growing importance of patient preference and adherence throughout the therapeutic continuum. Patient satisfaction, acceptability, quality of life, compliance, persistence and their role in developing new therapeutic modalities and compounds to optimize clinical outcomes for existing disease states are major areas of interest for the journal. This journal has been accepted for indexing on PubMed Central. The manuscript management system is completely online and includes a very quick and fair peer-review system, which is all easy to use. Visit http:// www.dovepress.com/testimonials.php to read real quotes from published authors. 